Öztürk, Ahmet Erdi, and Semiha Sözeri. "Diyanet as a Turkish foreign policy tool: Evidence from the Netherlands and Bulgaria." Politics and Religion 11, no. 3 (2018): 624-648.

Published online by Cambridge University Press: 02 March 2018

Submitted: 26 July 2017, Accepted: 18 November 2017

\title{
DIYANET as a TURKISH FOREIGN POLICY TOOL: EVIDENCE FROM THE NETHERLANDS and BULGARIA ${ }^{1}$
}

\begin{abstract}
How does Turkey's Presidency of Religious Affairs (Diyanet) act as an instrument of foreign policy? What are the factors that allow such an instrumentalization of Islam in Turkish foreign policy? In addressing these questions, this article uses semi-structured expert interviews from Bulgaria and the Netherlands. Although both countries host a sizeable Muslim minority, these populations differ in their characteristics and historical ties with Turkey. Comparing Diyanet's role in the Netherlands with its recent Turkish Muslim diaspora, and in Bulgaria with its centuries-old Muslim minority allows us to reveal variation in the practical engagement strategies that Diyanet adopts in different country contexts. Thus, the article advances two main claims; first, Diyanet serves as a primary foreign policy tool of Turkey in countries with a significant Turkish-Muslim minority. Secondly, this instrumentalization destabilizes secularization projects both at home and abroad.
\end{abstract}

Key words: Diyanet, foreign policy, state apparatus, Netherlands, Bulgaria, AKP, Turkey, religion

\section{INTRODUCTION}

While religion has long been a salient force in world politics, scholarly interest in the role of religion in international relations (IR) and foreign policy (FP) analysis was quite limited during the second half of the twentieth century. It was partly due to the hegemonic weight of

\footnotetext{
${ }^{1}$ We are grateful to Taptuk Emre Erkoç, Samim Akgönül, İştar Gözaydın, Efe Kerem Sözeri, Bahar Baser, Guy Ben-Porat, Ayse Kadayıfcı-Orellana, Simon P. Watmough, Anne-Laure Zwiling, Kerem Öktem, and two anonymous reviewers for their helpful and constructive comments on the earlier versions of this article. We also would like to thank the editors of the Journal of Politics and Religion for their kind approaches.
} 
secularization theory, but prompted by the events of $9 / 11$ and ethno-religious conflicts around the world, scholars are increasingly turning to the role of religion in FP (Sandal and Fox 2013). As the field has blossomed, scholars have been investigating a range of topics, including the effect of religion in peacebuilding (Gurses and Rost 2017; Gurses 2015), faith-based diplomacy (Marsden 2014), and the role of religion, particularly Evangelicals, in American FP (Amstutz 2013; Inboden 2008). Secularization theorists have also predicted that, over time, political penetration of religious institutions could decline (Finke and Stark, 1992) but, recent developments signal that religions might take on institutional forms and become major players in politics and FP (Kalyvas 1996).

Gill and Keshavarzian (1999) argue that religious institutions represent focal points that influence how societies, polities, and economies operate. While Ben-Porat's (2013) Israel case demonstrates that religious institutions constrain secularization projects, effective roles of religious institutions for political mobilization show that Islamic institutions can mobilize both democratic and anti-Western protests in the Arab world (Wiktorowicz 2004; Stephan and Linz 2013). While the roles of the Catholic Church in democratic transitions in Catholic countries were remarkable (Philpott 2004; Gill 1998), Buddhist institutions also influenced prodemocracy movements in Thailand, Myanmar and Tibet (Cheng and Brown 2006). Therefore, it is difficult to ignore the role of religious institutions in FP (Warner 2000; Ammerman 2003). Warner and Walker $(2011,125)$ note that religions' political influences on FP might be facilitated by transnational institutions. As a result of globalization, transnational religious actors and institutions such as the Roman Catholic Church, al Qaeda and Shia networks have various levels of power in FP (Haynes 2009). Furthermore, religious institutions can internationalize domestic struggles as well (James and Ozdamar 2005; Ghose and James 2005). Drawing on this literature, one may argue that religious institutions do not have fixed modes of 
operation and outputs, and thus, they may have both positive and negative effects on secularisation processes, internal socio-political processes, and bilateral relations in FP.

Philpott $(2007,518)$ notes that the role of state identities has provided an entry point for research on religious institutions' impact on FP. Countries' religious heritages also affect their FP orientation and religious institutions' strategies (Warner and Walker 2011, 115). What is still lacking, however, is a clear theoretical account of precisely how, to what extent, religious institutions function positively or negatively to certain FP outcomes. The co-existence of religion and its instrumentalization via institutions in FP is, therefore, an opportunity to ask: Why and how do states instrumentalize their religious institutions as a FP tool? And, in which circumstances do they cause positive or negative outputs?

Against this backdrop, this article is concerned with the strategic use of one of Turkey's religious institutions, the Presidency of Religious Affairs (Diyanet), as an instrument of FP under the ruling Justice and Development Party (Adalet ve Kalkınma Partisi, AKP). Based on a comparative analysis of Diyanet activities in Bulgaria and the Netherlands, the article advances two key claims: 1) Diyanet has been instrumentalized in a number of important dimensions in the new Turkish foreign policy (TFP) that reflects an Islamist identity and interests. 2) Diyanet's instrumentalization has been destabilizing secularization projects both at home and abroad. Linked to the general research questions above, this article poses subquestions: a) Why and how does AKP instrumentalize Diyanet as a FP tool? b) What factors determine Diyanet's scope of activity in each country case? and c) What are the effects of instrumentalization of Diyanet in FP for both Turkey and host countries? 
The article begins with an overview of the evolution of laiklik and Diyanet and scrutinizes the transformation of both under AKP rule. Secondly, it explains of the reformulation of new TFP and Diyanet's role since 2002.. Thirdly, it compares the role of Diyanet in the country cases. Lastly, in the conclusion part, the article claims two main points: 1) Diyanet serves as a primary foreign policy tool of Turkey in countries with a significant Turkish-Muslim minority. 2) this instrumentalization destabilizes secularization projects both at home and abroad.

\section{RELIGION AND POLITICS IN MODERN TURKEY: A SYNOPSIS}

Since 1937, Turkey has been defined officially as a secular (laik) state, despite having a Sunni Muslim-population. However, laiklik (laïcité and/or secularism) in the Turkish context is sui generis, it does not correspond to a secular separation of religion and state, but rather denotes state control (i.e. legal regulation) of religion in the public sphere. Laiklik was thus the concept preferred by early republican decision makers in all legislation and legal regulations. Laiklik was also one of the building blocks of Turkey's modernization (Keyman 2007, 217), until the rise of the AKP.

Since 2002, Turkey has witnessed consecutive single-party governments under the AKP, which has a pro-Islamic leadership cadre. Initially advancing a pro-democratic agenda, it has since 2010 taken a clear authoritarian turn, instrumentalizing both nationalist and pro-Islamist rhetoric to mobilize support and smother opposition (Baser and Öztürk 2017). The new policy preference has influenced both the state identity and FP orientation because they are intertwined in Turkey's context. AKP has also transformed Diyanet into a pliable state apparatus geared towards implementing the political ideology of the party. The transformation of Diyanet is not limited to domestic policy, but extends to the new TFP, which has acquired an ethno-religious 
identity. Moreover, through the instrumentalization of Diyanet abroad, the AKP has been exporting domestic matters to the diaspora and other Muslim communities.

To understand the AKP's turn and some of the Diyanet activities both at home and abroad after 2013, it is obligatory to mention one actor that has been effecting Turkish political life substantially: Gülen Movement. It is a controversial Turkey-originated transnational Islamic movement active in education, media and business world (Fitzgerald 2016). Gülen Movement seems to be an example of interfaith dialogue through the prism of civil society in global level, however, it also has a political face dedicated to expansion of their political and bureaucratic power and aiming to reach important positions within the state (Hendrick 2013). Although the Movement has started to place its members to the state cadres at the beginning of 1980s, their presence in public offices has reached its peak during the AKP period and become an unofficial coalition partner of the governments. Furthermore, the Movement has expanded its activities abroad and worked as an arm of the AKP. Yet, following political crises such as the December 15-17 corruption scandal and the July 15 coup attempt, this unofficial coalition was dispersed. As a result, the government labelled Gülen Movement as Fethullah Gülen Terror Organization (FETÖ). Therefore, particularly in the aftermath of the coup attempt Turkey has been openly combating the Movement's institutions both at home and abroad via its transnational institutions, such as Diyanet.

One of the main pillars of laiklik is Diyanet; founded in 1924 as an administrative unit within the Turkish state and charged with the management of religion. In fact, its establishment predates the constitutional enshrinement of the doctrine of laiklik itself, which came in 1937. Practically speaking, Diyanet's functions include the regulation of Sunni Islamic doctrine, practice, and schooling, as well as the maintenance of places of prayer. Since the late 1970s, it 
has also been active abroad, particularly in countries with significant Turkish diasporas and Muslim minorities. This is also the period when the salience of Islamic identity began to increase in both society and the state.

Due to its unique historical background and institutional structure, defining Diyanet is not easy. It could be defined as a religious actor, an institution or an epistemic community. Sandal (2011) argues that the role of religious actors in today's political scene qualifies them as an epistemic community due to their expertise and status, and for that reason religious epistemic communities are eligible to influence the politics in a global level. The epistemic community approach of Sandal could be applied to Diyanet, but its character of a state institution and bureaucratic missions necessitate a more diversified definition.

Althusser (2014) defines the state as composed of an infrastructure and a superstructure which takes the form of different state apparatuses of both repressive and ideological nature. The repressive ones are agencies under state control meant to impose the dominant ideology over the society by violence and coercion. The ideological ones are not directly under state control and instead reside within the private domain of society. Nevertheless, they still serve to transform the society in line with state objectives by exercising non-coercive and indirect forms of social control. Diyanet - strictly speaking - is neither. It is legally under state control, but the use of violence would be inconceivable. Yet, as specified by Ali Bardakoğlu (2004, 397368), a former president (between 2003-2010) of Diyanet; "it has a particular role in the production and transmission of religious knowledge... provides sound religious information”. However, Diyanet has engaged in identity and ideology construction on the one hand, for example by issuing fetvas (Islamic legal opinions), and forms of social control on the other, such as gathering intelligence for the national intelligence services. ${ }^{i}$ Therefore, it stands in- 
between an ideological and repressive state apparatus. Nevertheless, it has a distinctively religious focus, and its characterization as a religious state apparatus seems sensible.

Regarding Turkey's laiklik, Zürcher $(2004,233)$ argues that “secularism meant not so much the separation of church and state as the subjugation and integration of religion into the state bureaucracy." Laws introduced in 1924-25 not only laid down the basis for laiklik, but also deputized Diyanet as the sole locus of official Islam (Akgönül 2005) on behalf of the state, thus establishing its status as a religious state apparatus. To explain the role of Diyanet in laiklik, Gözaydın $(2008,216)$ claims that "the ruling elite both took religion under their control and managed to break the potentially sacred significance of Diyanet". These provisions reveal that the founding fathers recognized the social importance of religion, and the need to compromise with historical-social reality inherited from the Ottomans. They were determined to control the influence of religion and to introduce a framework for the state that excluded religious justifications. Therefore, laiklik is sui generis in three ways. First, it has been an interpenetrating concept drawing on Western philosophy and the legacies of the Ottomans. Secondly, the state has been the progenitor focal point of laiklik. Finally, it was a key constituent element of state identity.

Starting from late 1940s, within the multi-party system, political parties realized that religious rhetoric could be transformed into votes. Therefore, Diyanet gradually took control over the Quran courses and endowments (vakıflar) in favour of political actors. A new constitution in 1961 recast the ideological work of Diyanet, attributing it a new mission to "enlighten" society about the proper conduct of religion and the moral aspects of Islam. Furthermore, between 1960 and 1980 Diyanet became the meeting point of "official" and "unofficial" Islam. During this period of loosened restrictions on communal religious practice, many members of alternative Islamic communities such as Nakşibendi, and Nurcu found official positions in Diyanet (Bruce 2015, 87-95). 
Under the right-wing governments of the 1970s, Diyanet received a further boost. The Turkey Diyanet Foundation (Türkiye Diyanet Vakfi, TDV) was established in 1975 and received taxexempt status in 1978. It has provided crucial financial support for the activities of Diyanet both in Turkey and abroad ever since. In 1978, eighteen Turkish Consulates for Religious Services (Din Hizmetleri Müşavirliği) were established in Germany, and twenty-one Attachés for Religious Services (Din Hizmetleri Ataşeliği) were appointed by Diyanet at the Turkish embassies in Europe, the Unites States and Australia (Çı1tak 2010, 611-622).

Another breakthrough for Diyanet came with the 1982 Constitution, which embodied new ideological identity elements, most notably the so-called Turkish-Islamic Synthesis. Article 136 enshrined Diyanet's new role as a progenitor of "national unity": "Diyanet, ... shall exercise its duties ... in accordance with the principles of laiklik, removed from all political views and ideas, and aiming at national solidarity and integrity" (Constitution of the Republic of Turkey 1982). Islam was to play a leading role in national unity and Diyanet was made constitutionally responsible in advancing that objective. Furthermore, the promotion of Turkish Islam abroad, especially in countries with Turkish immigrant populations, was added to Diyanet's mission. Its role in the FP, however, is not limited to migrants with a Turkish background. It has emerged as an actor in the international arena aiming to construct and promote the new ethno-religious identity of Turkey. For instance, to control and regulate mosques and other religious activities on behalf of Diyanet, Türkisch-Islamische Union der Anstalt für Religion (Diyanet Iş̧leri Türk Islam Birliği, DİTIP) was founded in Germany in 1985, where the Turkish diaspora is the most numerous.

\section{INSTRUMENTALIZATION OF DIYANET UNDER AKP RULE}

Diyanet has been among the most politicized of all administrative structures during the AKP period, especially since 2010. Its budget (as shown in Graph 1), administrative capacity and 
activities have been gradually expanding. In 2011, Diyanet started issuing halal certificates, in 2012 it opened a TV station, and its foundation, TDV, opened a university. Its fetvas and press statements touched upon gender issues, social media, political economy, and relations with social groups which reflect AKP's political discourse. Diyanet was thus strategically employed in the domestic context to legitimize AKP policies via religious sanction, which had a chilling effect on dissent and opposition (Öztürk 2016).

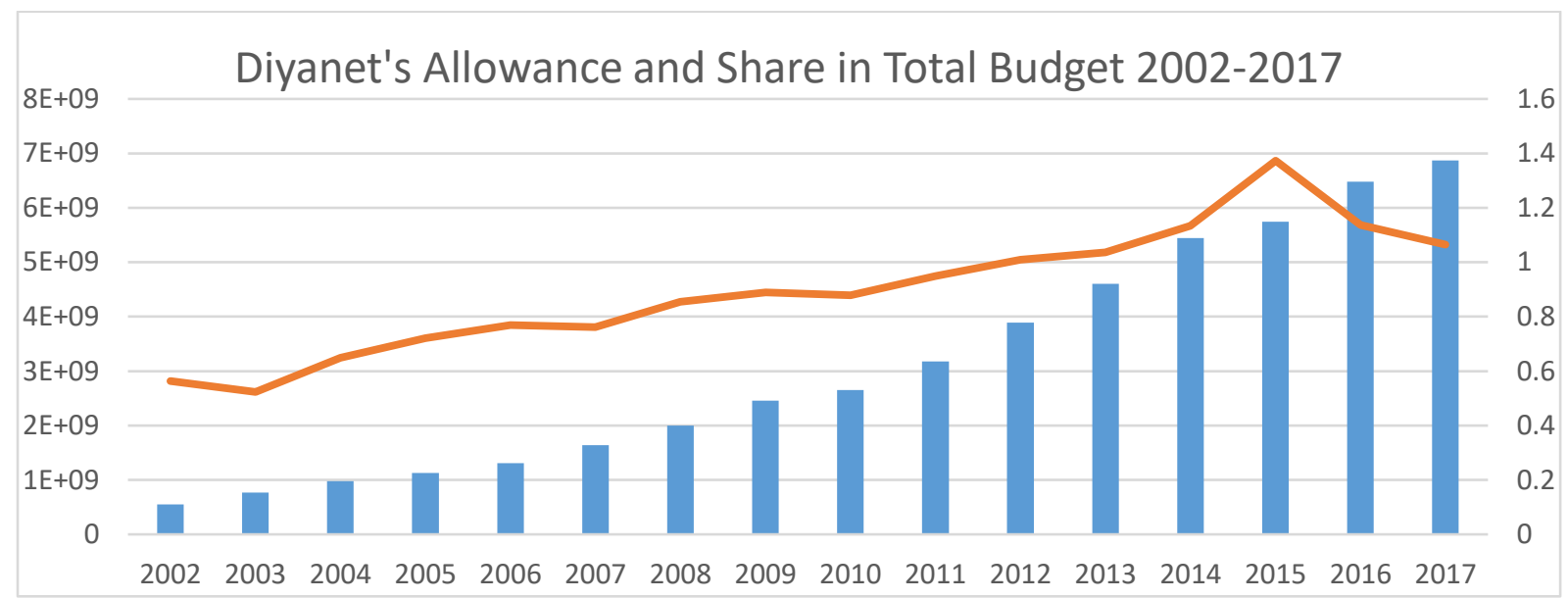

Graph 1: Diyanet's budget under the AKP rule. Source; The Turkish Ministry of Finance.

Since the early republican era TFP has been an extension of domestic politics, and this relation has not changed during the AKP period. Both the increasing Islamization of the AKP agenda and the strengthening of Diyanet have been manifested in the new TFP. During the AKP period, the enlargement of Diyanet's sphere of influence is one of the indicators that political elites have tried to spread the identity change of the state to the society both at home and abroad. Therefore, Diyanet has become both a bureaucratic tool and a social actor. This reveals two additional points. First, the instrumentalization of Diyanet has destabilized the Turkish laiklik project by securing a multidimensional influence for its religious state apparatus structure. Secondly, overabundant transnationalization of Diyanet has made it one of the international symbols of Turkey with its new religious state identity. 
TFP has traditionally hued to a realist orientation with four principles: Westernization, a commitment to a stable international order, adherence to law, and laiklik. According to Yavuz (1997, 23), “foreign relations filtered down from the secular elite's self-ascribed European identity, which in turn was the basis of framing Turkish national interest". At the beginning of the 1970s political Islam was strong enough to challenge the laik and Western-oriented identity of the state, but was not strong enough to change it. While traces of a shift may be observed during Turgut Özal's period as prime minister and president (1983-1993), the paradigm shift to a more religious-oriented state identity has taken place primarily during AKP rule (Sözen 2010). With ideological roots in the nationalist Islamic movement Milli Görüş (National Outlook), the AKP elite has used ethno-religious rhetoric in both domestic politics and in its FP agenda. This would be achieved by the ideational father of pan-Islamic foreign-policy doctrine, Ahmet Davutoğlu. He argued that Turkey could become a global power in the postCold War context "as long as it followed an expansionist FP based on Islamist ideology" (Ozkan 2014, 119).

His 2001 book "Strategic Depth" (Stratejik Derinlik) outlined what an ethno-religiously oriented TFP would look like. For Davutoğlu, identity - alongside Turkey's geopolitical position - provided the country with strategic depth. A shared Ottoman-Islamic identity provided Turkey with a potential integrative FP capacity in its relations with countries from the Balkans to the Arab Gulf and beyond. Islam, according to him, is ontologically distinct from other civilizations, particularly the West. He characterizes the emergence of the Islamic state as a product of the expansion of Western international society and its nation-state domination into the region, especially noting the creation of "artificial" national borders after the collapse of the Ottomans (Davutoğlu 2001). Considering this, it is no surprise that AKP policies carved a space for Diyanet both as a state apparatus, but also as a religious diplomacy actor. Mehmet Görmez, the former President of Diyanet between 2010-2017, asserted precisely that role for 
the organization. ${ }^{\text {ii }}$

While President Erdoğan ousted Davutoğlu as prime minister in 2016, his TFP mentality has remained. One can argue that under AKP rule, Sunni Islam has replaced laiklik as one of the identity constituents of TFP. Prioritization of the Islamic identity has been interpreted as increasing soft power in TFP. Although religious soft power is acknowledged within FP, the change in TFP under the AKP cannot be solely explained by increasing soft power, or by a change in political leadership. It is the reformulation of state identity through shifting worldviews and discourses of the political elite. Moreover, the political elites of the AKP have preferred to transform the duties of the state apparatuses to implement the new TFP. In this regard, Diyanet is a case in point.

To illustrate, while foreign minister, Davutoğlu spoke at a Diyanet conference of the concept of the "heart hinterland" (gönül cografyası), a reference to the global Muslim community. Davutoğlu charged Diyanet with structuring its role abroad with this concept in mind. ${ }^{\mathrm{iii}}$ In line with this vision in 2017, Görmez, defined the institution both as an international power that claims to be a reference point for all Muslims and as the "flotation ring" around the world. iv After Görmez's sudden resignation in July 2017, Ali Erbaş, was appointed as the new president of Diyanet and his words in the handover ceremony were telling about Diyanet's global vision: "We have to work more than ever to deliver the eternal call of Allah and the Prophet to humanity, which is endangered by secularism and nihilism". ${ }^{\circ}$

Increasing prominence of Islamist discourse in TFP was also reflected in Turkey's position on the Syrian issue and the problems with Israel. Yavuz $(2016,440)$ describes these FP stances as Islamist, anti-Western, adventurist, and ideological. Therefore, axial dislocation and employment of religion as an identity tool in the new TFP have been distinguishing themselves in three different ways. It was primarily constructed by domestic political evolvements of 
AKP's Islamism and political elites' worldviews. Secondly, the new TFP tries to influence Muslim societies via both religious discourse and supporting activities. At last, Turkey has been positioning itself as a Muslim country in the international system.

Given this, it is not strange that Diyanet as a religious state apparatus has been playing a substantial role via its transnational institutional capacity both among Muslim and non-Muslim societies. Diyanet has adapted itself to the new TFP and its religious identity with 61 branches in 36 countries. Furthermore, it has been publishing and distributing Qurans and religious books in 28 languages and it has been financially supporting official Muslim representative institutions in the Balkan Peninsula, Europe and Africa via TDV. It has been also supplying educational and material support for the foreign countries' imams. During the AKP period, it has been building mosques around the world. Diyanet also has been organising official meetings such as Balkan Countries Islam Council, and Latin American Countries' Muslim Summit. Taking all this into consideration, in the following sections we will demonstrate the strategic utilization of Diyanet in TFP under the AKP rule and the issues arising from it by analyzing the Dutch and the Bulgarian context in comparative perspective.

\section{METHODOLOGY AND DATA COLLECTION}

Our analysis is based on data from semi-structured expert interviews conducted in Bulgaria and the Netherlands. The Dutch data (N=29) was collected between July 2016 and January 2017. The sample includes representatives of major Turkish migrant and Islamic umbrella organizations, including Diyanet, Milli Görüss, Süleymancılar, Gülen movement, Contact Organ for the Muslims and the Government (CMO), Stichting Platform Islamitische Organisaties Rijnmond (SPIOR), Euro-Mediterraan Centrum Migratie en Ontwikkeling (EMCEMO), Hollanda Türkiyeli İşçiler Birliği (HTIB) and Hollanda Atatürkçü Düşünce Derneği (HADD). The respondents were imams, Quran teachers, chairs of the organizations, Islamic theologians, 
academic experts on the Turkish diaspora, and policy-makers working in the field of integration and radicalization. The Bulgarian data $(\mathrm{N}=28)$ was collected in April 2017 and the sample includes representatives of the Turkish state in Bulgaria, political and bureaucratic elite of Bulgaria, expert journalists, representatives of Gülen Movement, representatives of Bulgarian Muslims and other religious organizations.

The asked questions inquired into the perceptions of key local actors about Diyanet and Turkey. Some questions specifically focused on the (perceived) role of Diyanet in the social and political lives of the Muslim and Turkish communities in both countries. Other questions asked about the cooperation between Diyanet and state institutions in the host countries and the public opinion about it. Even though the subject and many of the questions were the same in both countries, respondents in the Netherlands were promised confidentiality due to the political sensitivity of the issues related to Diyanet's activities in the Netherlands, while most of the Bulgarian informants agreed to use their names in this study; there are only four anonymous interviewees in the Bulgarian case. The difference in respondents' attitude to confidentiality might be related to the fact that the Dutch-Turks are descendants of guest-worker migrants, and are still nationals of both the Netherlands and Turkey. As such, they feel more pressure regarding their freedom of expression around issues related to the involvement of Turkey in the Netherlands. Bulgarian-Turks and Muslims, on the other hand, are an indigenous minority in Bulgaria. They are almost exclusively only Bulgarian nationals, and thus, find themselves in a safer position to openly discuss politically sensitive questions.

A comparative analysis of these two countries is interesting for several reasons. First, both the Bulgarian and the Dutch government adhere to an official separation of religion and state. Although Christianity retains cultural dominance, religion has been relatively limited in foreign policymaking. This is in stark contrast to current Turkish understanding. Secondly, both 
countries host a significant number of Turkish-originated Muslims. In the Netherlands, the Muslim community constitutes about $6 \%$ of the total population (Berger 2014) with more than half originating from Turkey. Similarly, Muslims in Bulgaria who mostly self-identify as ethnically Turkish or Pomak make up 6\% of the total population (Popov 2013), and there are sources that claim that this percentage might be around $12 \%$ (Global Economy data 2013). Turkey has demonstrated historically a vested interest in promoting Turkish and Islamic identity among the Muslim minorities both in Bulgaria and in the Netherlands. In both country cases, but especially in the Netherlands, double citizenship additionally provides Turkey with a space for political claims-making over the national and religious loyalties of its citizens abroad.

Furthermore, comparing the Bulgarian and the Dutch contexts allows us to differentiate between the FP agenda employed by Diyanet vis-à-vis "the new" and "the old" Muslims of Europe. Despite their similarity of size, these Muslim populations differ in their characteristics and historical ties with Turkey. While Dutch Muslims are mostly immigrant guest-workers and their descendants who settled in the country in the 70's and 80's, Bulgarian Muslims are considered indigenous minority who has been around since the Ottomans have set foot on the Balkans and whose migration to Bulgaria is too dated to be directly traced. Despite that, similar to Muslims in the neighbouring Balkan countries, the Bulgarian Muslims are often perceived as remnants of the Ottomans and the links between the Bulgarian Muslims and Turkey have been politicized both under the communist regime and after it. Turkey's claims on its right to interfere into social and political affairs of the Bulgarian Muslim minority have been voiced stronger during the AKP period. Comparing Diyanet's role under the influence of new TFP in the Netherlands with its relatively new Turkish Muslim diaspora and in Bulgaria with its centuries old Muslim minority allows us to uncover the similarities and differences in the 
discursive strategies and practical involvement adopted by Diyanet in two significantly different contexts.

\section{THE NETHERLANDS: THE CONTROVERSIAL ROLE OF DIYANET IMAMS IN TURKISH DIASPORA'S LIFE}

Today there are 475 mosques in the Netherlands and Diyanet controls a plurality of them: 146 mosques in total. The Dutch branch of Diyanet was established in 1982 with the aim to counteract the potentially divisive influence of leftist asylum-seekers and rightist members of alternative Islamist movements such as Milli Görüş, and to increase loyalty toward the Turkish state (Yükleyen 2009). In 1983, the Netherlands and Turkey signed an agreement allowing Turkey to send its own imams to cater to the religious needs of the growing Turkish-Muslim community of guest-workers (Sunier, van der Linden, and van de Bovenkamp 2016). In the 1980s and 1990s, many Western European governments adopted the Dutch approach and supported the import of imams through Diyanet. Given Diyanet was controlled by a laik state, its vision of Islam was seen as more "moderate" and acceptable (Sunier and Landman 2015). Nevertheless, both in the past and now there have been critical voices warning against allowing a foreign state to exert influence over the lives of European Muslims (Binswanger and Sipahioğlu, 1988, 75). For example, one of the academic experts in our sample put it this way:

The interesting thing is that back in the early 1990s when there was this agreement between Diyanet and several governments in Europe for sending imams and these people had special kind of work permit. At that time governments were glad about it because they thought, well, imams trained in Turkey, this is the kind of moderate Islam controlled by the state. And there was nothing about what it is now. It is a completely different discussion now. The governments are very much against it. They really would rather see the whole system wound up. 
This is indicative of the heavy criticism in the Dutch public discourse levelled against Diyanet. Critics argue that it hinders the effective integration of Dutch-Turkish Muslims. It employs imams who do not speak Dutch and are thus unfamiliar with the Dutch social context. Additionally, it promotes allegiance to the Turkish state without promoting loyalty to the Dutch state (Sunier, van der Linden, and van de Bovenkamp 2016). Finally, Diyanet has facilitated a fusing of politics and religion that others have condemned. It has, for example, allowed propaganda of the Dutch political party DENK (founded by Dutch-Turks and DutchMoroccans) in the mosques it controls. DENK is known to be close to the AKP government. ${ }^{\mathrm{vi}}$ Moreover, some respondents argue that Diyanet and the religious attaché have divisive influence on the different Turkish diaspora organizations by importing Turkey's domestic problems and by imposing the official state position on migrant organizations. A representative of HTIB, a pioneering migrant organization for Turkish guest-workers' rights, highlighted one recent example during our interview: The Turkish migrant organizations in the Netherlands had all been requested to join a statement against domestic violence. However, the religious attaché of the Turkish Embassy declared that "domestic violence does not exist in the Turkish society" and that "whoever engages in it is a national traitor". Following this, all Turkish Islamic organizations withdrew their signatures from the statement.

A similar dynamic has been observed in importing the domestic post-coup tensions between the AKP and Gülen movement to the Dutch context. The chair of a Diyanet mosque commented that after the coup attempt, the number of Dutch-Turkish students attending their mosque classes more than doubled because "before they [the Gülenists] used to divide us and now the citizens have become more united." Both examples illustrate the way in which for the Turkish diaspora declaring national allegiance to Turkey is intertwined with demonstrating loyalty to its Islamic institutions such as Diyanet. Under these circumstances, one can claim that there is a significant change of Turkey's and Diyanet's perception among the Dutch society, since 
Turkey has been instrumentalizing its religious state apparatus to propagate its new ethnoreligious identity and involving Dutch politics as well.

\section{Diyanet and the Training of Dutch Imams}

The change in attitude towards Diyanet and the foreign imams started in the post-9/11 context, when the Dutch government announced a call for subsidies for Dutch imam-training programs in 2004 (Johansen 2006). Leiden University, Vrije University Amsterdam and Inholland University of Applied Sciences received 4.2 million euro in total for establishing Dutch Islamic theology programs that are set up to train Islamic preachers who are familiar with the European context and who espouse Dutch values and norms (Ghaly 2008, 379-386). To be meaningful, these undertakings would have to ensure that the Islamic communities in the Netherlands agree to employ the students after graduation. Neither Leiden University, nor Vrije University Amsterdam managed to complete such agreements with the representatives of the Islamic communities. Although Inholland was more successful in this respect (agreements were signed with the two Dutch branches of Milli Görüş, the Süleymancı community, the Moroccan umbrella organization Unie van Marokkaanse Moskeeorganisaties in Nederland, and the Surinamese umbrella organization World Islamic Mission), notably Diyanet stayed out of all initiatives for Dutch imam-training programs (Meuleman, 2012, p. 233). When asked about the reasons for the lack of support by Diyanet, a senior executive from CMO remarked that:

Diyanet does not want to collaborate because if they do, it would become much more difficult for them to bring their own imams from Turkey.

Similarly, a high-profile representative of Milli Görüş expressed its discontent with the lack of cooperation by Diyanet in this respect:

They were supposed to organize this training in collaboration with Inholland; all Islamic organizations would sign the agreement. Then it turned out Diyanet had not signed it. 
Unavoidably something like that happens among us. Why does Diyanet refuse to sign?

Because they still want to bring their own imams from Turkey!

The lack of support by Diyanet for Dutch imam-training programs exemplifies the fact that the raison d'être of the Dutch Diyanet expands beyond serving the religious needs of the Turkish citizens. It implies that the Turkish government has vested interests in deciding who preaches what messages in Dutch-Turkish mosques. The evidence is clear: Diyanet's position on imam training flows from Turkey's desire to maintain its capacity to control appointments of Turkish imams (who are presumably accountable to Ankara) and thus to use Diyanet's religious state apparatus structure transnationally.

\section{Imams or Religious Diplomatic Officials?}

Many of our respondents in the Netherlands were employed by the Dutch Diyanet. Before their placement, they go through a very competitive selection process in Ankara for the appointment of religious officials (imams) abroad. In our interview, a senior member of Diyanet reported that the annual number of Diyanet imams appointed to European mosques "varies between 500 and 1000". In his words, every year "between 140,000 and 130,000 Turkish religious officials enter the foreign placement exam" which has three parts: a written test about their Islamic knowledge, an oral exam testing Arabic pronunciation and presentation skills, and an interview with the Culture Commission comprised of officials of the Ministry of Culture and Ministry of Foreign Affairs. One of the high-ranking Diyanet officials in the Netherlands described the questions and the objectives of the interview with the Culture Commission in the following way:

For instance, they had asked us what are the Copenhagen criteria, the headquarters of the European Parliament, the current president, the secretary. [...] They ask such questions also to understand whether you belong to an institution with a state tradition. 
[...] Because you are in a foreign country, you follow the orders of the Ministry of Foreign Affairs here. And you have to be under the supervision of the Embassy and the Consulate. And you have to represent your state in the best possible way in the foreign country you are posted to. In other words, they are looking for someone who will not engage in controversial actions that are at odds with the state tradition. And they try to identify the officials who will abstain from humiliating deeds while they are representing the state abroad.

Comparable to diplomatic officials, according to figures provided by a former chair of the Dutch Diyanet, every Diyanet imam in the Netherlands costs Turkey around $€ 5,000$ per month. In other words, Turkey has similar expectations and offers comparable benefits to its foreign affairs officials and imams employed abroad. The provision of such arrangements, which equate the status of diplomats and religious officials, facilitates the inclusion of religious rhetoric in the political conversation in the international arena. Under the new ethno-religious identity of the Turkish state the imams sent abroad seem to become prominent representative figures of Turkey in the international arena.

\section{"The Long Arm of Erdogan": Accusations of Espionage}

An extension of the debate about the political tasks given to imams at the Dutch Diyanet touches upon allegations of gathering intelligence. Following the coup attempt of July 15, 2016, Diyanet mosques have been accused of espionage against supporters of Gülen movement and other opponents of AKP. One of the most contested examples is the recall of Yusuf Acar, the religious attaché at the Turkish Embassy in The Hague and the chair of the Dutch Diyanet, from his position in December 2016. After leaked correspondence between Acar and the Turkish government, he was accused of instructing the imams in Diyanet mosques to carry out intelligence activities and of providing intelligence himself such as reporting the names of 
Dutch sympathizers of Gülen Movement. Among the reported names there were politicians of the Christian Democrat Party CDA as well. The Turkish ambassador was summoned by the Dutch Parliament to respond to the allegations and as a result, Acar was withdrawn from his position and sent back to Turkey. It is noteworthy that before his departure, Acar had confessed on Dutch national television that he has collected information about Gülen supporters in the Netherlands. He has, however, denied having instructed other imams to gather intelligence as well.

The diplomatic tensions aroused by the Acar affair speak volumes about the dynamic behind the instrumentalization of Diyanet as a foreign policy tool. The case itself is illustrative of the nature of Diyanet as a religious state apparatus having a social control mechanism not only at home but also abroad. ${ }^{\text {vii }}$ Despite Acar's denial of the spying allegations, the publicity around the case indirectly serves Turkish state's purposes by revealing to the diaspora that its actions are being monitored and reported to the Turkish government. In this way, both domestic conflict and domestic surveillance practices are exported abroad via Diyanet.

\section{BULGARIA: THE CHANGING FACE OF THE TURKISH BIG BROTHER}

As mentioned previously, the Bulgarian case differs from the Dutch in a number of ways. Süleyman Gökçe, Turkey’s Sofia Ambassador between 2013-2017, declared that “...the Balkans are very important for us because of its historical and democratic ties with us, but Bulgaria is much more important. Here, we have many kin who speak a certain language, who believe in a certain book. Yet, they suffered during the communist period and we have to assist them." Indeed, after more than five centuries of Ottoman rule, Bulgaria gained independence in 1878, but the remaining Muslims and Turks were defined as "others" by the Bulgarians. They were mostly alienated from politics and bureaucracy. Even though some of the legal regulations took the religious and national identities under protection during the communist period (1946- 
1990), Bulgarian Muslims suffered due to the prohibitions of mother-tongue education, Turkish names, and Islamic practices.

In this regard, one of the chancellors of the Grand Mufti's Office in Sofia remarks that "...it was so sad that Turkey could not do anything for us during the communist period, but we never drop Turkey from our hearts...”.

According to the current Grand Mufti, Mustafa Hadzihi, "although the Muslim denomination continued to exist during the communist period, none of the Grand Mufti's were representatives of Bulgarian Muslims, they acted according to the Bulgarian state and they did not work for Turks' and Pomaks' rights." Yet, after the assimilation campaign led by Todor Zhivkov, the First Secretary of the Central Committee of the Bulgarian Communist Party between 19811989, reinstating the rights of the Turks and Pomaks was among the first democratic acts of the new regime in Bulgaria. Mihail Ivanov, one of the head advisors of Zhelyu Zhelev, the first post-communist President of Bulgaria between 1990-1997, stated that:

Our aim was to establish democratic Bulgaria and we knew that we have to supply religious service to Muslims, but we did not have money and educated staff. Our borders were now open and first Jordan and the Saudis realized that. This was frightening for us since they might radicalize our Muslims. Our expectation was to get some assistance from secular Turkey, but they were not strong and rich enough during the beginning of 1990s.

Although there was a gradual shift in the state identity of Turkey in 1990s, it was still accepted as a laik country. In this period, not Turkey, but Gülen Movement entered the Bulgarian field. According to the current representative of the Movement, during the late 1993 they started to support Grand Mufti's Office financially and took control of Momchilgrad, Shumen and Ruse Imam Hatip high schools, but their unique position disappeared in 1998. The main reason has 
to do with 28 February process in Turkey initiated with the military memorandum and the decisions issued by the Turkish military leadership on a National Security meeting on February 28, 1997. This memorandum started the process that precipitated the resignation of the first Islamist prime minister of Turkey, Necmettin Erbakan of the Welfare Party. Beyond this effect, Turkey tried to pacify unofficial religious movements both at home and abroad. Therefore, Diyanet and TDV signed the first financial support agreement with the Bulgarian Grand Mufti to eliminate the role of Gülen Movement, but Grand Mufti Hadzihi noted that until 2003 Turkey could not manage to pay all the items in it.

\section{Islamization of Turkey's Perception and Visibility of Diyanet}

Most Bulgarians welcomed the AKP ascendency in 2002. The Grand Mufti declared that "I was so sure that rationalist Erdoğan would be more beneficial for us than the other Turkish leaders". Member of the Bulgarian Parliament from the Socialist Party Ivo Hristov mentioned that "to have a pro-EU and democratic neighbor was a dream come true for Bulgaria.” Furthermore, Grand Mufti Hadzihi added that:

Starting from the beginning of the AKP period material and nonmaterial support [from Turkey] has been gradually increasing. Currently we are getting almost two million Bulgarian Lev and other material resources, there are twelve imams here right now and I can say that they are a locomotive for our imams who serve in more than 1100 mosques all over Bulgaria. These are not enough since we cannot get any support from the Bulgarian government due to the Constitution, but we are so lucky that we have Erdoğan who truly understands us.

At this point, one might claim that although AKP's Turkey was not perceived as an Islamist, it has started to use its religious state apparatus from the early periods. 
Despite Hadzihi's positive opinions, one of the former members of the Parliament from the prominority rights party Movement for Rights and Freedoms (Движение за права и свободи, DPS) claimed that:

Especially after 2010, it is obvious that Erdoğan has started to use Diyanet for his political aims in Bulgaria. Currently, the Turkish Embassy is in the second rank and the real representative is Diyanet and its imams. Erdoğan has established a Muslim Turkey and he is an indisputable leader. It is true that Bulgarian Muslims are not that devoted but especially Turks have been touched by this idea. And with regards to Davutoğlu's ideas even though the Bulgarian state has been underestimating them, but Turks and Pomaks like it. I am afraid this policy will cause many problems.

According to same chancellor in the Grand Mufti’s office, “starting from 2010, Erdoğan's and Davutoğlu's religious discourse has started to make us happy, but just five minutes after that we started to ask about how it will affect us. This is Bulgaria. They [the authorities] will never let political Islamic discourse in here". Thus, one might argue that AKP started to export its Islamic discourse abroad wherever there are significant Muslim minorities and the dramatic change has been perceived as troublesome by some groups. Furthermore, comparable to the Dutch case, since 2010 Diyanet's representative position as a diplomatic actor has come to light.

\section{The Same Long Arm of Erdoğan in Bulgaria}

Similar to the Dutch case, late 2013 was crucial for Diyanet's role in the relations between Turkey and Bulgaria. Mihail Ivanov defined that period with these words: "we managed to escape radical Islam in 1990s, but now, I am not sure how will we ward off Turkey's political Islam." The conflict between AKP and Gülen Movement reflected on Bulgaria directly. According to the representative of Gülen Movement following indirect directives of Diyanet, 
all staff with close relations to the Movement were dismissed from Grand Mufti's Office and almost all of the mosque community members took their children from Gülen-affiliated schools. According to a senior foreign ministry staff in Sofia; "since 2014 almost every month we have been getting some complaints from local political elites regarding Turkish imam activities and their pro-Erdoğanist discourse in mostly Blagoevgrad, Targovishte and Razgrad where Turks and Pomaks are a majority." This is almost the same situation observed in the Dutch case: exportation of domestic conflicts via Diyanet.

Second issue is about the Bulgarian domestic policy. Since 1990, DPS has been seen as the political representative of Bulgarian Turks. After the founding leader Ahmed Dogan, Lyutvi Mestan took the chair, but after two years he was removed by the central council and expelled from the party for what it considered an excessively pro-Turkish government stance following the downing of a Russian bomber jet by the Turkish air force. Mestan subsequently founded a new political force, Democrats for Responsibility, Solidarity and Tolerance (Демократи за отговорност, свобода и толерантност, DOST). According to Hristov, almost everyone is sure that DOST was founded at the request of Erdoğan and Diyanet imams helped it set up. Bulgarians feel that Erdoğan's aim is both to meddle in Bulgarian domestic politics and also propagate his Islamic discourse among Turks and Pomaks. By doing so, Hristov argued that Erdoğan has changed the perception of Turkey among Bulgarians. As a result, Bulgarians do not see Turkey as secular and democratic anymore.

Related to the DOST-DPS division and parallel with the Dutch case, "the long arm of Erdoğan" issue took place in Bulgaria as well. The Bulgarian press reported on February 21, 2017 that Uğur Emiroğlu, Diyanet's official in Bulgaria, was declared "persona non-grata” for engaging in activities in the religious sphere. Emiroğlu's activities in Bulgaria were deemed "incompatible with his diplomatic status", although the nature of the activities was not specified. According to Bulgarian press, Emiroğlu had been pressuring the Bulgarian Muslims 
to support DOST. Although Hyusein Hafazov, vice-president of DOST declared that "all allegations are without any evidence and ridicules", a senior officer in Bulgarian foreign ministry said that "we did not do anything without solid evidence".

Based on the Bulgarian case one may claim that Diyanet has been playing an active role in promoting AKP's Islamic discourse abroad. Furthermore, as illustrated by the tensions around the purge of Gülenists, it has been used as an apparatus to export the domestic conflicts by using its material and non-material resources. At last, new TFP has stated to change Turkey's laik state identity and made religion an issue to other countries' subject matter. Alexander Oscar, president of one of the most visible and active religious communities in Sofia, the Jewish community (Shalom), highlights that "unfortunately Turkey seems to be an Islamic and authoritarian country now. It makes us unhappy since we have very good relations with Bulgarian Muslims and the Mufti, but this new situation will destroy that." Therefore, the construction of Turkey's new state identity is not related to the interaction with others. Instead the main driver is domestic politics and the political elite's attitudes. The Islamization and authoritarianization of Erdoğan's Turkey has been manifesting itself in FP preferences. As in the Dutch case, religion is both an objective and an instrument for Turkey while shaping policy preferences for Bulgaria.

\section{CONCLUSION}

In this article, using the case studies of Bulgaria and the Netherlands, we have demonstrated the strategic instrumentalization of Diyanet in the new TFP under the AKP governments. We argued that this instrumentalization has been made possible thanks to the employment of a religious FP vision constructed on a political discourse about the binding power of religious identity. The analysis of the case studies shows that the growing importance of Islam in the 
rhetoric used in domestic politics is directly reflected in the activities of the Turkish state abroad, leading to the evolution of Diyanet into an influential religious actor and rising the status of imams into religious diplomats.

With its hegemonic position in Turkish politics, AKP has succeeded in integrating a religious discourse in various fields of policymaking expanding Diyanet's sphere of influence more than any of its predecessors. These changes would not be feasible without replacing the laik state identity with a Sunni Islamic one. The promotion of Sunni Islam among Turkish and Muslim communities abroad has become both an objective and a means to a greater aim: The retention of control over these minorities and through that, socio-political influence in the host societies. As shown in the case of increasing number of students in Diyanet mosques in the Netherlands and decreasing number of students in Gülenist schools in both countries after the coup attempt, the rhetoric employed by Diyanet in addressing the Turkish and Muslim minorities abroad has been equating religious allegiance with national allegiance, combining all opponents of the AKP regime under the label "national traitors".

Comparable with Ben-Porat's (2013) analysis of the case of the Israel's internal politics, the instrumentalization of Diyanet in TFP is also indicative of the extent to which religious institutions can be detrimental to national secularization projects. Also, we see that it has a divergent destabilizing effect on the understanding of separation of church and state in the country cases as well. The official understanding of separation of church and state in the Netherlands seems to be more affected by the political claims-making of the Dutch Diyanet as seen in the considerations about the profile of religious actors that motivate educational policies and state funding for imam-training programs. Although the Bulgarian political elite is also wary of Diyanet's meddling in their internal affairs, attempts to finance and control the Bulgarian Grand Mufti's office by the Bulgarian state are absent. The reason behind the differing impact of Diyanet on the secularism of Bulgaria and the Netherlands might be related 
to their respective pasts. During the communist regime, the identity of the Bulgarian state has been atheist, making all religious practices illegal. In contrast to that, despite the official separation of church and state in the Netherlands, all religious denominations have enjoyed freedom of practice and representation thanks to the Dutch pillarization system (late 1800s1980s) in which the society was organized around religious pillars, each pillar having its own media and political parties.

Their different pasts notwithstanding, the interviews in both cases point out that Turkey's abandonment of its own laik identity and the political powers it bestows upon its religious state apparatus led to the creation of Turkey's new image as a not-so-moderate Islamic state. This is in line with the argument advanced by Philpott (2007) on the critical role played by religious institutions in determining state identities. The diplomatic crises around the Turkish religious attachés both in Bulgaria and the Netherlands illustrate the more general resistance by European countries against the new religious identity of the Turkish state and FP role acquired by Diyanet. Particularly in the post-coup tensions between AKP and Gülen Movement abroad in which Diyanet was also involved, we observe what James and Ozdamar (2005) and Ghose and James (2005) referred to as the potential of religious institutions to internationalize domestic political issues.

Further research comparing the reception of Diyanet's branches in France, Germany, Sweden, Austria and USA may provide valuable insights about the role of religious institutions in FP. Many Western countries hosting sizeable religious or ethnic diasporas are struggling with finding appropriate responses to the contentious attempts for influence on their minorities from the countries of origin. In this respect, our findings might have implications for policymaking directed at regulating the rights and powers of foreign religious institutions. Last but not least, the findings of our study might also provide a stepping stone for scholarly work further 
investigating the influence of religious institutions on bilateral relations between diasporas' host countries and countries of origin.

\section{REFERENCES}

Althusser, Louis. 2014. On the Reproduction of Capitalism: Ideology and Ideological State Apparatuses. London: Verso Books.

Ammerman, Nancy T. 2003. "Religious Identities and Religious Institutions." Handbook of the Sociology of Religion, 207-224.

Amstutz, Mark R. 2013. Evangelicals and American Foreign Policy. Oxford: Oxford University Press.

Bardakoglu, Ali. 2004. "'Moderate Perception of Islam' and the Turkish Model of the Diyanet: The President's Statement." Journal of Muslim Minority Affairs 24: 367-374.

Baser, Bahar, and Ahmet Erdi Öztürk. 2017 "In Lieu of an Introduction: Is it Curtains for Turkish Democracy? In Authoritarian Politics in Turkey: Elections, Resistance and the AKP, eds. Baser, Bahar and Ahmet Erdi Öztürk London: IB Tauris: 1-20.

Ben-Porat, Guy. 2013. Between State and Synagogue: The Secularization of Contemporary Israel. Cambrdige: Cambridge University Press.

Berger, Maurizio. 2014. "The Netherlands". In Oxford Handbook of European Islam, ed. Cesari, Jocelyne, Oxford: Oxford University Press, 1-80.

Binswanger, Karl, and Fethi Sipahioğlu. 1988. Türkisch-islamische Vereine als Faktor Deutsch-türkischer Koexistenz [Turkish-Islamic Associations as a Factor in the German-Dutch Coexistence]:75. München: Rieß.

Cheng, Tun-jen, and Deborah A. Brown 2006. "Introduction: The Roles of Religious Organizations in Asian Democratization." In Religious Organizations and Democratization: Case Studies from Contemporary Asia, eds. Cheng, Tun-jen, and Deborah A. Brown, Armonk, NY: M.E. Sharpe, 3-40.

Constitution of the Republic of Turkey, Turkish Grand National Assembly, 1982, https://global.tbmm.gov.tr/docs/constitution_en.pdf (Accessed July 1, 2017).

Çitak, Zana. 2010. "Between 'Turkish Islam'and 'French Islam': The Role of the Diyanet in the Conseil Français du Culte Musulman." Journal of Ethnic and Migration Studies 36: 619634.

Davutoğlu, Ahmet. 2001. Stratejik Derinlik. Istanbul: Küre Yayınlar1.

Finke, Roger., and Rodney Stark. 1992. The Churching of America, 1776-1990: Winners and Losers in Our Religious Economy. New Brunswick: Rutgers University Press. 
Fitzgerald, Scott T. 2017. "Conceptualizing and Understanding the Gülen Movement." Sociology Compass 11(3):1-10..

Ghaly, Mohammed M. 2008. "The Academic Training of Imams: Recent Discussions and Initiatives in the Netherlands". In The Study of Religion and Training of Muslim Clergy in Europe, eds. Drees, Willem B., and Pieter Sjoerd van Koningsveld. Leiden: Leiden University Press:379-386.

Ghose, Gauvav, and Patrick James. 2005. "Third-party Intervention in Ethno-religious Conflict: Role Theory, Pakistan, and War in Kashmir, 1965." Terrorism and Political Violence 17(3): 427-445.

Gill, Anthony, and Arang Keshavarzian. 1999. "State Building and Religious Resources: An Institutional Theory of Church-State Relations in Iran and Mexico." Politics \& Society 27(3): 431-465.

Gill, Anthony. 2008. Rendering unto Caesar: the Catholic Church and the State in Latin America. Chicago: University of Chicago Press.

Global Economy Data. 2013. Bulgaria: Muslims as Percent of the Total Population. http://www.theglobaleconomy.com/Bulgaria/muslim/ (Accessed on July 4, 2017).

Gözaydın, İstar B. 2008. "Diyanet and Politics." The Muslim World 98: 216-227.

Gurses, Mehmet. 2015. "Is Islam a Cure for Ethnic Conflict? Evidence from Turkey." Politics and Religion 8 (1): 135-154.

Gurses, Mehmet, and Nicolas Rost. 2017. "Religion as a Peacemaker? Peace Duration After Ethnic Civil Wars." Politics and Religion 10: 339-362.

Haynes, Jeffrey. 2009. "Transnational Religious Actors and International Order." Perspectives 17: 43-69.

Hendrick, Joshua D. 2013. Gülen: The Ambiguous Politics of Market Islam in Turkey and the World. New York: NYU Press.

Inboden, William. 2008. Religion and American Foreign Policy, 1945-1960: The Soul of Containment. Cambridge:Cambridge University Press.

James, Carolyn C., and Özgür Özdamar. 2005. "Religion as a Factor in Ethnic Conflict: Kashmir and Indian Foreign Policy." Terrorism and Political Violence 17(3): 447-467.

Johansen, Brigitte Shepelern. 2006. Islam at the European Universities: Report II. Research Priority area "Religion in the 21 st Century". Copenhagen: University of Copenhagen.

Kalyvas, Stathis N. 1996. The Rise of Christian Democracy in Europe. New York, Cornell University Press.

Keyman, E. Fuat. 2007. "Modernity, Secularism and Islam: The Case of Turkey." Theory, Culture \& Society 24: 215-234.

Marsden, Lee. 2014. "Faith-based Diplomacy: Conservative Evangelicals and the United States Military." Politics and Religion 7(3): 475-498. 
Meuleman, Johan. 2012. "Educating for an Old Profession in a New Context: The Imam Training Programme of Inholland University, the Netherlands". In The Training of Imams and Teachers for Islamic Education in Europe, eds. Aslan, Ednan, and Zsofia Windisch. EBSCO Publishing: E-book collection: 233.

Ozkan, Behlül. 2014. "Turkey, Davutoglu and the Idea of Pan-Islamism." Survival 56: 119140 .

Öztürk, Ahmet Erdi. 2016. "Turkey's Diyanet under AKP Rule: From Protector to Imposer of State Ideology?." Southeast European and Black Sea Studies 16: 619-635.

Philpott, Daniel. 2004. "The Catholic Wave." Journal of Democracy 15(2): 32-46.

Philpott, Daniel. 2007. "Explaining the Political Ambivalence of Religion." American Political Science Review 101: 505-525.

Popov, Radko. 2013. "Islam in Modern Bulgaria: 1878 to Present". Occasional Papers on Religion in Eastern Europe 33 (2): 1-6. http://digitalcommons.georgefox.edu/ree/vol33/iss2/1/ (Accessed July 4, 2017).

Samim, Akgönül. 2005. Religions de Turquie, Religions des Turcs: Nouveaux Acteurs dans l'Europe Élargie. Paris: L'Harmattan.

Sandal, Nukhet Ahu. 2011. "Religious Actors as Epistemic Communities in Conflict Transformation: The Cases of South Africa and Northern Ireland." Review of International Studies 37(3): 929-949.

Sandal, Nukhet, and Jonathan Fox. 2013. Religion in International Relations Theory: Interactions and Possibilities. Oxfordshire: Routledge.

Santing, Froukje, and Lily Sprangers. 2013. "De Groeiende Invloed van Turkije op de Turkse Diaspora in Nederland" Internationale Spectator 67 (11): 39-43. https://www.internationalespectator.nl/article/de-groeiende-invloed-van-turkije-op-de-turksediaspora-nederland (Accessed on July 4, 2017).

Sözen, Ahmet. 2010. "A Paradigm Shift in Turkish Foreign Policy: Transition and challenges." Turkish Studies 11: 103-123.

Stepan, Alfred, and Juan J. Linz. 2013. "Democratization Theory and the "Arab Spring"." Journal of Democracy 24(2): 15-30.

Sunier, Thijl, and Nico Landman. 2015. Transnational Turkish Islam. Shifting Geographies of Religious Activism and Community Building in Turkey and Europe. London: Palgrave Macmillan.

Sunier, Thijl, van der Linden, Heleen, and Ellen van de Bovenkamp. 2016. "The Long Arm of the State? Transnationalism, Islam and Nation-building: The Case of Turkey and Morocco". Contemporary Islam 10 (3): 401-420.

Warner, Carolyn M., and Stephen G. Walker. 2011. "Thinking About the Role of Religion in Foreign Policy: A Framework for Analysis." Foreign Policy Analysis 7 (1):113-135.

Warner, R. Stephen. 2000. "Religion and New (Post-1965) Immigrants: Some Principles Drawn from Field Research." American Studies 41(2/3): 267-286. 
Wiktorowicz, Quintan, ed. 2004. Islamic Activism: A Social Movement Theory Approach. Indiana University Press: 2004.

Yavuz, M. Hakan. 1997. "Turkish-Israeli Relations Through the Lens of the Turkish Identity Debate." Journal of Palestine Studies 27: 22-37.

Yavuz, M. Hakan. 2016. "Social and Intellectual Origins of Neo-Ottomanism: Searching for a Post-National Vision." Die Welt des Islams 56: 438-465.

Zürcher, Erik J.2004. Turkey: A Modern History. London: IB Tauris.

\footnotetext{
${ }^{\mathrm{i}}$ The Cumhuriyet newspaper published a report on 8 December proving that the Diyanet had gathered intelligence via imams from 38 countries on the activities of suspected followers of Fethullah Gülen. See; http://www.almonitor.com/pulse/originals/2017/02/turkey-europe-new-crisis-spying-imams.html ii $\quad$ https://webdosya.diyanet.gov.tr/anasayfa/UserFiles/Document/TextDocs/49e2ccfd-ea35-4827-bbf1d81c2a90175e.pdf

iii See, https://www.diyanet.gov.tr/tr/icerik/yurt-disindaki-tarihi-ve-dini-mirasin-korunmasinda-diyanet-isleribaskanligina-cok-buyuk-vazifeler-dusuyor/7447? getEngdlish

iv See, https://webdosya.diyanet.gov.tr/anasayfa/UserFiles/Document/TextDocs/49e2ccfd-ea35-4827-bbf1d81c2a90175e.pdf

$\checkmark$ http://www.hurriyetdailynews.com/turkeys-new-top-cleric-enters-office-vows-to-continue-struggle-againstfeto.aspx?pageID=238\&nID=118113\&NewsCatID=341

${ }^{v i}$ See 'Vormt het Turkse Diyanet een veiligheidsrisico voor Nederland?' ('Does the Turkish Diyanet constitute a security threat for the Netherlands?') by Afshin Ellian, 22 March 2017, Elsevier (http://www.elsevierweekblad.nl/nederland/blog/2017/03/vormt-het-turkse-diyanet-een-veiligheidsrisico-voornederland-475839/), and 'DENK krijgt steun van Ankara in verkiezingscampagne' ('DENK receives the support of Ankara for the election campaign') by Eric Vrijsen, 11 February 2017, Elsevier (http://www.elsevierweekblad.nl/nederland/achtergrond/2017/02/denk-krijgt-steun-van-ankara-inverkiezingscampagne-451208/)
} 